Artículo original

\title{
Diagnosis and observations of a hybrid hummingbird (Metallura tyrianthina $x$ Aglaiocercus kingi) in the Eastern Andes of Colombia
}

\author{
F. Gary Stiles*, José Oswaldo Cortés-Herrera \\ Instituto de Ciencias Naturales, Universidad Nacional de Colombia, Bogotá, Colombia
}

\begin{abstract}
An unusual, strikingly colored male hummingbird present for several months in the Rogitama Biodiversity Reserve in Boyacá, Colombia created considerable media attention. It was initially suggested that the bird might represent the rediscovery of the Bogotá Sunangel, Heliangelus zusii. However, a later study of its DNA identified $H$. zusii as a member of a clade that includes Aglaiocercus and Taphrolesbia. Given the many differences in plumage from the Rogitama hummingbird, this hypothesis was rejected. Three hypotheses regarding its identity were examined in detail: it could represent an unusually colored male of Aglaiocercus kingi, a hybrid between two local species, or an undescribed species. We observed this bird's foraging and interactions with other hummingbirds, recorded its song and captured it to describe in detail its plumage and take morphological measurements, after which it was released. We rejected all hypotheses except that of a hybrid, and concluded that A. kingi and Metallura tyrianthina were its probable parents. In contrast to its plumage and morphometrics, its song was unlike those of its putative parents, possibly representing a transgressive character. The same may be true of the bluish coloration (termed "hybrid bluing") that characterized several hybrids between green-backed parental species, including the Rogitama hummingbird.
\end{abstract}

Key words: Colombia, interspecific hybrid, Rogitama reserve, transgressive character, Trochilidae.

Diagnosis y observaciones de un colibrí híbrido (Metallura tyrianthina x Aglaiocercus kingi) en la cordillera Oriental de Colombia

\section{Resumen}

Un extraño colibrí macho de colores llamativos, presente durante varios meses en la Reserva Natural Rogitama Biodiversidad de Boyacá, Colombia, suscitó considerable atención en los medios de comunicación. Inicialmente se sugirió que este individuo representaba el redescubrimiento de Heliangelus zusii, pero un estudio reciente de su ADN reveló que $H$. zusii era una especie dentro del clado que incluye a Aglaiocercus y Taphrolesbia. Dadas las numerosas diferencias entre el plumaje del holotipo de $H$. zusii y el colibrí de Rogitama, se rechazó esta hipótesis. Entonces, se consideraron en detalle las siguientes tres hipótesis sobre su identidad: podría tratarse de un macho de Aglaiocercus kingi con un plumaje anormal; de un híbrido entre dos especies de la región, o de una especie nueva sin describir. Se observó su comportamiento de forrajeo y su interacción con otros colibríes, se grabó su canto y, con el fin de describir su plumaje y tomar medidas morfométricas, se le capturó y después se le soltó. Se rechazaron todas las hipótesis excepto la que postulaba que se trataba de un híbrido, y se concluyó que sus padres probablemente pertenecían a A. kingi y Metallura tyrianthina. A diferencia de su plumaje y morfometría, su canto era diferente al de las dos especies parentales y posiblemente representaba un carácter transgresivo. Lo mismo podría afirmarse del color azul del plumaje, característico de varios híbridos entre especies de dorso verde, incluido el colibrí de Rogitama.

Palabras clave: Colombia, carácter transgresivo, híbrido intergenérico, Reserva Rogitama, Trochilidae.

\section{Introduction}

The Reserva Rogitama Biodiversidad is situated in the Eastern Andes of Colombia ( $\left.5^{\circ} 47^{\prime} \mathrm{N}, 73^{\circ} 27^{\prime} \mathrm{W}\right)$ at an elevation of ca. $2530 \mathrm{~m}$ in the municipality of Arcabuco, department of Boyacá. This 29 ha reserve was purchased 32 years ago by Roberto Chavarro, at which time it consisted mostly of highly degraded and eroded cattle pasture with a small patch of disturbed native oak forest. Since then, the Chavarro family has been engaged in restoring this habitat: first by planting resistant exotic trees to provide shade and improve the soil, then progressively reintroducing native vegetation, protecting the watercourses and improving remaining pastures with agroforestry techniques. In the 
gardens around the house, they have planted various species with flowers visited by hummingbirds, especially Fuchsia boliviana and Abutilon species and varieties as well as native species including bromeliads, ericads and others, which has made this area a Mecca for hummingbirds. To date, over 100 species of birds have been recorded in the reserve, including 12 species of hummingbirds, of which the endemic and threatened Black Inca, Coeligena prunellei (locally called the "Príncipe de Arcabuco") is among the most common (Chavarro 2009).

In October of 2011 a spectacular new hummingbird appeared that was unlike any species of the area or indeed, of Colombia. This bird (Figure 1) had the general aspect of a male sylph (Aglaiocercus) but was dark greenish-blue with a long, shining purple tail, a brilliant green crown and blue gorget. Immediately speculations abounded in the national ornithological community and shortly, in the national and international press and in the internet regarding the identity of the "Rogitama Hummingbird" - first with respect to its possibly representing the rediscovery of the Bogotá Sunangel Heliangelus zusii described by Graves (1993), never seen in the wild and categorized as "critically endangered” by BirdLife International (2001). Further speculation centered on the possibility of its being a new species or a hybrid. The bird remained at Rogitama for several months and well over 200 visitors saw it, with the last sighting in April 2012; it has not returned since. Here we present the results of our study of this bird, including its probable identity and observations on its behavior and vocalizations.

\section{Methods and Materials}

Field observations: JOCH made $c a$. 8 h of observations of the bird on eight visits between November 2011 and February 2012 from distances of 4-15 m, recorded its vocalizations on a Sony ICD-PX720 recorder and prepared sonograms with the Raven program. He also recorded vocalizations of a Metallura tyrianthina male at Rogitama in March 2011, and of a male Aglaiocercus kingi at Laguna Gervase in Arcabuco in April 2011 and made the corresponding sonograms of their songs.

Capture, plumage description and measurements: On 8-9 December 2011 FGS visited Rogitama with the object of capturing the bird to make a thorough description of its plumage and take detailed morphological measurements. The bird was duly captured in a mist net; its plumage colors were described with reference to the color swatches of Smithe (1971, 1975), and the following measurements were taken to the nearest $0.1 \mathrm{~mm}$ with a Tajima dial caliper:

\footnotetext{
*Corresponding author:

F. Gary Stiles, fgstilesh@unal.edu.co

Recibido: 7 de julio de 2015

Aceptado: 1 de septiembre de 2015
}

length of exposed and total culmen; commissure width (between each corner of the mouth); height of the bill at the midpoint of the operculum; length of the chord of the folded wing; length of the tail from the insertion of the middle pair of rectrices, and the length of each rectrix from the same point; tarsus length; foot extension (the maximum extension of the foot with the claws firmly gripping the points of the calipers); and the chord of the hallux claw (see Stiles 2004, 2009 for further details). A tracing (planform) of the extended wing was taken and its length and maximum chord (width) measured with calipers, as above. The area of the planform was measured with a planimeter and the following aerodynamic parameters calculated: wing loading in $\mathrm{g} / \mathrm{cm}^{2}$, shape and aspect ratios, and wing taper (see Stiles et al. 2005 for details). The bird was weighed to the nearest 0.05 g with a $10 \mathrm{~g}$ Pesola spring scale, after which the bird was released. It flew to a nearby perch and preened for ca. $3 \mathrm{~min}$ and was seen feeding from the flowers of Fuchsia boliviana within 30 min and repeatedly thereafter.

\section{Results}

Description of the Rogitama Hummingbird: The long, deeply forked tail and brilliant crown and gorget indicate that the bird was an adult male. There were no signs of immaturity: it had no corrugations on the maxillary rhamphotheca and its central rectrices were rounded at the tip, not pointed as in many young hummingbirds and a reliable indicator of immaturity once the bill striations have been lost, which usually occurs within 2-4 months of fledging (FGS, pers. obs.). Viewed from above, the crown was dark green, tinged with blue (between 162A, Dark Green and 74, Cyanine Blue) but viewed from the front, the entire crown reflected brilliant pale green (nearest 162D, Opaline Green); from the nape and sides of the head to the upper tail-coverts, the dorsal plumage was very dark blue (near 74, Cyanine Blue) with a green sheen (darker than 62, Spectrum Green), the overall effect viewed from above dark greenish blue; the entire upperside of the tail was brilliant dark purple (near 172A, True Violet), the tips and borders of the rectrices reflecting brilliant blue (270, Ultramarine). The gorget was brilliant blue (between 65, Turquoise Blue and 67, Cerulean Blue), tapering posteriorly to a blunt point; the breast was dark blue-green like the dorsum but the feathers had narrow pale gray borders (near 85, Pale Neutral Gray) giving a grizzled appearance when viewed from slightly below; these borders were broader towards the abdomen, especially medially, but the blue-green bases were visible under closer inspection; the sides and flanks were dark green, lightly tinged with blue and with narrow gray borders; the thigh tufts were white, the lower tail-coverts bluish green (between 160, Parrot Green and 164, Cyan) with broad, sharply defined buffy borders (123, Clay Color). The underside of the tail was dark, dull purple (darker than 172A, True Violet). The greater coverts and inner remiges were dark brown (near 221A, Warm Sepia) with a purple gloss (172, True Violet), the primary 

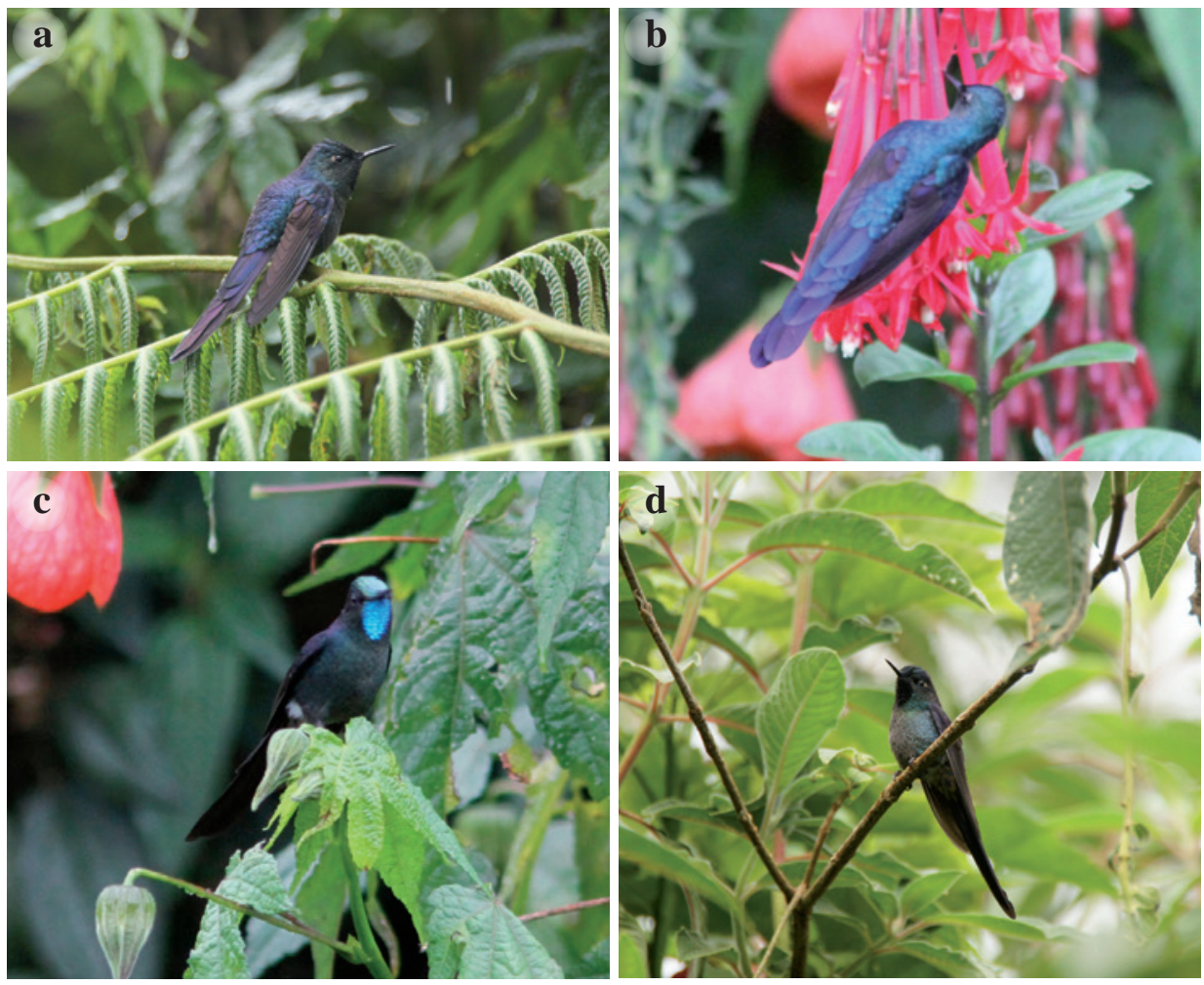

Figure 1. Four views of the Rogitama Hummingbird. a. perched in the understory; note the rather short bill; b. feeding while clinging to flower of Fuchsia boliviana: note bluish dorsal color, purple tail edged with blue; c. perched beside flower of Abutilon sp.; note colors of crown and gorget in good light; $\mathbf{d}$. perched in understory, viewed from below; note how colors of underparts change with viewing angle and backlighting, and the strong feet. Photos: a and d, J. Oswaldo Cortés-H.; b and c, Jurgen Beckers.

coverts and outer primaries were blackish, the latter glossed purplish distally. The iris was dark brown (near 22, Burnt Umber); the bill was black, the tarsi and feet blackish (82, Blackish Neutral Gray), the soles paler gray (84, Medium Neutral Gray) (see Figure 1). The body mass was $4.55 \mathrm{~g}$; the measurements were (in mm): exposed culmen 12.1, total culmen 14.5, commissure width 4.6, height of bill at midpoint of operculum 1.7, tarsus 5.5, foot extension 11.9, chord of hallux nail 3.6, chord of closed wing 63.7; the rectrices (measured from the insertion of the central pair) were 31.6, 35.0, 41.6, 54.0, 66.3; the outer rectrices were ca. $7.2 \mathrm{~mm}$ in width. A tracing of the extended wing was also taken; its length was 66.8, its maximum chord (width) was $22.0 \mathrm{~mm}$; the area of the wing was $11.72 \mathrm{~cm}^{2}$. Aerodynamic and shape parameters of wing were as follows: wing loading $0.194 \mathrm{~g} /$ $\mathrm{cm}^{2}$; wing shape (length/maximum width of extended wing) 3.036, aspect ratio 7.526, wing taper 0.248 .

Identity of the Rogitama hummingbird: Initially, there were four possible hypotheses regarding the identity of the Rogitama hummer: 1) it represented Heliangelus zusii ; 2) it was an abnormally colored individual of Aglaiocercus kingi; 3) it was a hybrid between two local species. Should hypotheses be rejected, one must consider 4) that it represented an undescribed species. We made comparisons of the measurements of the Rogitama bird with those of samples of adult males of other putative parental species taken by FGS (unpubl. data) in the course of a study of hummingbird ecomorphology (Stiles 2004, 2008).

Hypothesis 1: Heliangelus zusii.- Initially, speculation centered upon the possibility that the Rogitama bird represented the rediscovery of Heliangelus zusii. However, a detailed analysis of its plumage, in comparison with the description of H. zusii (Graves 1993) and photographs of the holotype of $H$. zusii kindly supplied by Gary Graves disclosed numerous differences leading to the rejection of this hypothesis. Among the salient differences were the much shorter bill of the Rogitama bird, the very different colors of the bright crown and gorget, secondaries and wing coverts, under tail-coverts, the color and pattern of the rectrices and the form of the secondaries (rounded vs. acuminate tips). Its tail was also definitely longer than the folded wing, the opposite from $H$. zusii.

Hypothesis 2: an abnormally colored male Aglaiocercus kingi.- The form and pattern of the tail, gorget and crown clearly suggest Aglaiocercus, and the colors of the crown and gorget resemble fairly closely those of A. kingi males. However, the colors of the rest of the plumage differ strongly. The Rogitama bird was much smaller in virtually all dimensions measured than males of A. kingi (Table 1); 
Table 1. Comparisons of measurements of the Rogitama hummingbird with the means, standard deviations and ranges for those of males of possible parental species: Aglaiocercus kingi, Metallura tyrianthina and Rhynchomicron microrhynchum.

\begin{tabular}{|c|c|c|c|c|}
\hline Measurement & $\begin{array}{c}\text { A. kingi } \\
\overbrace{}^{\top}(\mathbf{n}=13)\end{array}$ & $\begin{array}{l}\text { M. tyrianthina } \\
\hat{\jmath}(\mathbf{n}=\mathbf{2 5})\end{array}$ & $\begin{array}{c}\text { R. microrhynchum } \\
\curvearrowright \curvearrowright(\mathbf{n}=15)\end{array}$ & $\begin{array}{c}\text { Rogitama } \\
\text { hummingbird }\end{array}$ \\
\hline Exposed culmen & $\begin{array}{c}15.77 \pm 0.85 \\
(14.6-16.7)\end{array}$ & $\begin{array}{c}10.86 \pm 0.52 \\
(10.1-11.8)\end{array}$ & $\begin{array}{l}7.74 \pm 0.52 \\
(6.7-8.4)\end{array}$ & 12.1 \\
\hline Total culmen & $\begin{array}{c}18.61 \pm 0.74 \\
(17.7-20.3)\end{array}$ & $\begin{array}{l}12.51 \pm 0.62 \\
(11.5-13.4)\end{array}$ & $\begin{array}{c}10.21 \pm 0.97 \\
(8.9-11.4)\end{array}$ & 14.5 \\
\hline Comissure width & $\begin{array}{l}5.59 \pm 0.16 \\
(5.4-5.8)\end{array}$ & $\begin{array}{l}4.54 \pm 0.32 \\
(4.1-5.0)\end{array}$ & $\begin{array}{c}4.88 \pm 0.30 \\
(4.4-5.2)\end{array}$ & 4.6 \\
\hline Bill depth & $\begin{array}{c}1.88 \pm 0.12 \\
(1.7-2.0)\end{array}$ & $\begin{array}{c}1.45 \pm 0.09 \\
(1.3-1.6)\end{array}$ & $\begin{array}{c}1,54 \pm 0.06 \\
(1.4-1.6)\end{array}$ & 1.7 \\
\hline Length (chord)of closed wing & $\begin{array}{c}67.12 \pm 2.39 \\
(64.2-70.2)\end{array}$ & $\begin{array}{l}56.19 \pm 1.69 \\
(53.0-59.3)\end{array}$ & $\begin{array}{l}49.85 \pm 1.49 \\
(47.8-52.9)\end{array}$ & 63.7 \\
\hline Length of extended wing & $\begin{array}{c}72.94 \pm 2.65 \\
(67.7-74.5)\end{array}$ & $\begin{array}{l}61.12 \pm 1.66 \\
(58.2-64.2)\end{array}$ & $\begin{array}{c}54.18 \pm 1.94 \\
(50.9-57.8)\end{array}$ & 66.8 \\
\hline Maximum chord (width) of wing & $\begin{array}{c}23.31 \pm 0.67 \\
(22.2-24.3)\end{array}$ & $\begin{array}{l}21.49 \pm 0.77 \\
(20.2-23.1)\end{array}$ & $\begin{array}{c}17.97 \pm 0.55 \\
(17.1-18.9)\end{array}$ & 22.0 \\
\hline Form ratio of wing & $\begin{array}{l}3.129 \pm 0.064 \\
(3.041-3.234)\end{array}$ & $\begin{array}{l}2.846 \pm 0.073 \\
(2.689-2.958)\end{array}$ & $\begin{array}{l}3.015 \pm 0.069 \\
(3.049-3.204)\end{array}$ & 3.036 \\
\hline Aspect ratio of wing & $\begin{array}{l}7.773 \pm 0.291 \\
(7.241-8.322)\end{array}$ & $\begin{array}{l}7.184 \pm 0.286 \\
(6.626-7.544)\end{array}$ & $\begin{array}{c}7.503 \pm 0.278 \\
(7.04-8.09)\end{array}$ & 7.526 \\
\hline Wing loading & $\begin{array}{l}0.202 \pm 0.007 \\
(0.194-0.209)\end{array}$ & $\begin{array}{l}0.165 \pm 0.012 \\
(0.142-0.183)\end{array}$ & $\begin{array}{c}0.234 \pm 0.010 \\
0.184-0.304)\end{array}$ & 0.194 \\
\hline Wing taper & $\begin{array}{l}0.242 \pm 0.033 \\
(0.187-0.287)\end{array}$ & $\begin{array}{l}0.263 \pm 0.040 \\
(0.193-0.321)\end{array}$ & $\begin{array}{l}0.245 \pm 0.041 \\
(0.223-0.262)\end{array}$ & 0.248 \\
\hline Wing area & $\begin{array}{c}13.689 \pm 0.520 \\
(12.66-14.36)\end{array}$ & $\begin{array}{c}10.453 \pm 0.713 \\
(9.24-11.86)\end{array}$ & $\begin{array}{c}7.829 \pm 0.379 \\
(7.36-8.48)\end{array}$ & 11.72 \\
\hline Tail length & $\begin{array}{c}122.59 \pm 5.60 \\
(113.3-130.3) \\
n=10\end{array}$ & $\begin{array}{c}37.58 \pm 2.37 \\
(34.2-42.2)\end{array}$ & $\begin{array}{c}45.31 \pm 1.17 \\
(43.8-47.0) \\
n=9\end{array}$ & 66.3 \\
\hline Width of outer rectrices & $\begin{array}{c}6.45 \pm 0.21 \\
(5.9-6.8) \\
n=10\end{array}$ & $\begin{array}{c}8.23 \pm 0.24 \\
(7.7-8.6) \\
n=10\end{array}$ & $\begin{array}{c}6.51 \pm 0.19 \\
(5.9-6.6) \\
n=8\end{array}$ & 7.2 \\
\hline Tarsus length & $\begin{array}{c}6.18 \pm 0.21 \\
(5.9-6.4)\end{array}$ & $\begin{array}{l}5.52 \pm 0.24 \\
(5.0-5.9)\end{array}$ & $\begin{array}{c}6.07 \pm 0.15 \\
(5.8-6.4)\end{array}$ & 5.5 \\
\hline Foot extension & $\begin{array}{c}13.28 \pm \\
(12.5-14.3)\end{array}$ & $\begin{array}{l}11.60 \pm 0.35 \\
(10.9-12.0)\end{array}$ & $\begin{array}{c}11.99 \pm 0.49 \\
(11.1-12.7)\end{array}$ & 11.9 \\
\hline Chord of hallux nail & $3.91 \pm 0.26(3.5-4.4)$ & $\begin{array}{c}3.64 \pm 0.21 \\
(3.2-4.0)\end{array}$ & $\begin{array}{c}3.88 \pm 0.23 \\
(3.6-4.3)\end{array}$ & 3.6 \\
\hline Body mass & $\begin{array}{l}5.53 \pm 0.27 \\
(4.95-6.05)\end{array}$ & $\begin{array}{l}3.42 \pm 0.18 \\
(3.1-3.7)\end{array}$ & $\begin{array}{c}3.67 \pm 0.23 \\
(3.3-4.2)\end{array}$ & 4.55 \\
\hline
\end{tabular}

nearly all of its measurements were well below the lower extremes (and of the 95\% confidence intervals for the means) of the sample of $A$. kingi. We can therefore reject this hypothesis as well.

Hypothesis 3: a hybrid between two species present in the Rogitama region.- To show that the Rogitama hummingbird represents a hybrid, one must be able to identify its probable parents. Under this hypothesis, given that the inheritance of size and the details of color and pattern are undoubtedly polygenic in nature, the measurements of a hybrid should be intermediate between those of the putative parents, and its colors and patterns should also be intermediate or a mosaic of features of these (Graves 1997). One parent almost certainly would have been A. kingi, given its overall similarity in male crown and gorget and the shape and pattern of its long, brilliant tail. Given that the measurements of the Rogitama bird are much smaller than those of $A$. kingi, the other parent would necessarily have been a considerably smaller species. There are five species of smaller hummingbirds recorded from Rogitama or nearby areas: Chlorostilbon poortmannii, Adelomyia melanogenys, Chaetocercus mulsanti, Metallura 
tyrianthina and Ramphomicron microrhynchum. There are virtually no similarities between the plumage of the Rogitama bird and that of $A$. melanogenys, males of which are very bronzy on the dorsum and buffy, speckled with dusky below with a very different, well-marked facial pattern; they lack brilliant gorgets and crowns and have whitish-tipped rectrices. Similarly, there are virtually no points of similarity between the Rogitama hummingbird and C. mulsanti. C. poortmannii is much smaller in general, but its bill is actually longer than that of A. kingi, which immediately disqualifies it also as a possible parent (this is also the case with C. mulsanti).

The other two species do share several features of color and pattern with the Rogitama hummingbird and will be considered in detail. M. tyrianthina is uncommon at Rogitama, and while it has not been recorded there, $R$. microrhynchum is known from slightly higher elevations in the Natural Sanctuary of Iguaque, less than $10 \mathrm{~km}$ away and well within the range of seasonal movements of many highland hummingbirds in response to shifts in flower availability (cf. Gutiérrez 2005).

Nearly all measurements of the Rogitama hummingbird were intermediate between those of males of $A$. kingi and both putative parents (Table 1). We then compared the midpoints of the intervals between the mean measurements of males of each of these species with the corresponding measurements of $A$. kingi, assuming that the most probable parent should have the midpoints closer to the corresponding measurements of the Rogitama bird (Table 2). In 13 of 18 cases the measurements of the Rogitama bird agreed more closely with the A. kingi-M.tyrianthina midpoint than with the A. kingi-R. microrhynchum midpoint, including nearly all measurements of the wing, tail and feet. Moreover, in three of the five measurements favoring $R$. microrhynchum (body mass, wing shape, bill depth), the differences were very slight; only in the two measurements of bill length did the A. kingi-R. microrhynchum midpoints fall appreciably closer to the bill measurements of the Rogitama bird. A further comparison of measurements was made using the relative values (dividing the linear measurements by the cube of body mass to correct for absolute differences in size (Stiles 2004, Stiles et al. 2005). Eight of ten comparisons (one indeterminate) again favored $M$. tyrianthina; only the A. kingi-R. microrhynchum midpoint for total culmen is closer to that of the Rogitama bird (Table 3). Thus, the measurement data clearly provide more support for the second parent of a possible hybridization with A. kingi being $M$. tyrianthina.

A number of plumage characters lend support to this conclusion. The color of the tail of the Rogitama bird is much closer to that of $M$. tyrianthina, and its undertail coverts are

Table 2. Comparison of the measurements of the Rogitama hummingbird with the midpoints of the intervals between the mean measurements of Aglaiocercus kingi and those of Metallura tyrianthina and Ramphomicron microrhynchum from table 1.

\begin{tabular}{|c|c|c|c|}
\hline Measurement & Rogitama hummingbird & $\begin{array}{l}\text { Midpoint interval } \\
\text { A. kingi-M. tyrianthina }\end{array}$ & $\begin{array}{c}\text { Midpoint interval } \\
\text { A. kingi- } R \text {. microrhynchum }\end{array}$ \\
\hline Exposed culmen & 12.1 & 13.31 & $11.75^{*}$ \\
\hline Total culmen & 14.5 & 15.56 & $14.41^{*}$ \\
\hline Comissure width & 4.6 & $5.06^{*}$ & 5.23 \\
\hline Bill depth & 1.7 & 1.66 & $1.71 *$ \\
\hline Length of closed wing & 63.7 & $61.66^{*}$ & 58.49 \\
\hline Length of extended wing & 66.8 & $67.03^{*}$ & 63.56 \\
\hline Maximum chord of wing & 22.0 & $22.4^{*}$ & 20.64 \\
\hline Form ratio of wing & 3.036 & 2.988 & $3.014^{*}$ \\
\hline Aspect ratio of wing & 7.526 & $7.468 *$ & 7.638 \\
\hline Wing Area $-\mathrm{cm}^{2}$ & 11.78 & $12.070^{*}$ & 10.759 \\
\hline Wing loading - $\mathrm{g} \mathrm{cm}^{-2}$ & 0.194 & $0.183^{*}$ & 0.218 \\
\hline Wing taper & 0.248 & $0.250^{*}$ & 0.243 \\
\hline Tail length - adults & 66.3 & $80.08^{*}$ & 81.16 \\
\hline Width of outer rectrices & 7.2 & $7.34^{*}$ & 6.48 \\
\hline Tarsus length & 5.5 & $5.85 *$ & 6.12 \\
\hline Foot extension & 11.9 & $12.44^{*}$ & 12.64 \\
\hline Chord of hallux nail & 3.6 & $3.77 *$ & 3.89 \\
\hline Body mass & 4.55 & 4.48 & $4.60 *$ \\
\hline
\end{tabular}

An asterisk indicates the midpoint closest to the respective measurement of the Rogitama hummingbird. 
Table 3. Comparison of the relative measurements of the Rogitama hummingbird with the midpoints of the intervals between means for males of $A$. kingi and those of $M$. tyrianthina and R. microrhynchum.

\begin{tabular}{|c|c|c|c|}
\hline Measurement & Rogitama hummingbird & $\begin{array}{c}\text { Midpoint } \\
\text { A. kingi }- \text { M. tyrianthina } \widehat{\diamond}\end{array}$ & $\begin{array}{c}\text { Midpoint } \\
\text { A. kingi -R.microrhynchum } \widehat{\sigma}\end{array}$ \\
\hline Rel. exposed culmen & 7.54 & $8.07 *$ & 6.98 \\
\hline Rel.total culmen & 8.75 & 9.42 & $8.58^{*}$ \\
\hline Rel. commissure width & 2.78 & $3.08^{*}$ & 3.17 \\
\hline Rel. bill height & 1.03 & 1.02 & 1.04 \\
\hline Rel. folded wing length & 38.44 & $37.64^{*}$ & 35.19 \\
\hline Rel. extended wing length & 40.31 & $40.92 *$ & 38.25 \\
\hline Rel. tail length & 40.01 & $47.01^{*}$ & 58.04 \\
\hline Rel. tarsus length & 3.32 & $3.57 *$ & 3.72 \\
\hline Rel. foot extension & 7.18 & $7.61^{*}$ & 7.66 \\
\hline Rel. hallux nail chord & 2.17 & $2.32 *$ & 2.37 \\
\hline
\end{tabular}

An asterisk indicates the midpoint closest to the respective measurement of the Rogitama hummingbird.

very similar to those of that species. The entire dorsum of male $R$. microrhychum is uniform deep violet with no trace of green; in particular, there is little or no contrast between the body and tail colors. The dorsum of M. tyrianthina is green, in sharp contrast to the tail; however, Graves (1998) has noted that in several hummingbird hybrids, the dorsal green feathers are bluish, even when both parents had green dorsi, apparently due to alterations in melanin deposition (which produces the structural green color). The blue-green body color of the Rogitama bird could well be explained by such "hybrid bluing", especially because Graves (1998) observed this in another hybrid between the same two species. The colors and patterns of the underparts of both species are quite similar, but the duller green feathers of the breast and abdomen of $M$. tyrianthina tend to have faint grayish fringes (more like those of the Rogitama bird), whereas these feathers in adult male $R$. microrhynchum have grayish bases.

Hypothesis 4: an undescribed species.- Although we failed to reject the hybrid hypothesis, we feel that this fourth hypothesis deserves some mention, if only to show why it also merits rejection. First, given the amount of study of birds in the general region of Rogitama, it is highly unlikely that such a striking "species" should have escaped detection. Several areas at similar elevations, with similar forest types (oak and high Andean forests) are within relatively short distances of Rogitama and have received much attention from numerous observers and collectors, most notably Iguaque National Biological Sanctuary, less than $10 \mathrm{~km}$ S of Rogitama. Some $40 \mathrm{~km}$ NE of Rogitama are Virolín National Natural Park and the Guanentá-Fonce Natural Reserve. The latter site in particular is at a similar elevation to Rogitama and has been the site of several intensive studies of hummingbirds in recent years. In neither of these sites has anything like the Rogitama hummingbird ever been recorded. However, a "Bogotá" skin (without locality data) was reported by Meyer de Schauensee (1947) which, based upon the description supplied to him by Hno. Nicéforo, had plumage very similar to that of the Rogitama hummingbird and almost certainly represented another hybrid between the same two species. Unfortunately, this specimen cannot now be located.

Field observations of the Rogitama hummingbird: Because observations of a bird like the Rogitama hummingbird had been made at distances of 200-300m from the house at Rogitama, it was suspected that two birds were present. However, these distances could be covered in a few seconds by a hummingbird in continuous flight, and at no time were two birds seen simultaneously. We therefore conclude that only a single individual was present at Rogitama.

The Rogitama hummingbird was observed feeding at five kinds of flowers (Table 4). Those of the introduced Abutilon spp. and varieties and Fuchsia boliviana were abundant and continuously available during the observation period, whereas those of native species either had short blooming periods (Bejaria sp., frequently visited only in December) or were relatively scarce, accounting for the few recorded visits. The Rogitama hummingbird visited Abutilon flowers by inserting its bill into the nectar chamber via spaces between the petal bases from the outside of the corolla, either while hovering or perching on the corolla. All visits to Fuchsia flowers were made by inserting the bill into holes at the base of the corollas made by Diglossa flower-piercers (although the bird sometimes may have done its own piercing), usually while perched on the flowers themselves with its strong feet but occasionally while hovering. It also used Diglossa holes to visit flowers of Centropogon. When a nearby twig provided a convenient perch, it sometimes visited these flowers while perched thereon. Thus, at these flowers it acted as a nectar thief, not contributing to pollination (no 
Table 4. Numbers of visits by the Rogitama Hummingbird to flowers, observed between November 2011 and February 2012

\begin{tabular}{lcccc}
\hline Flower Species & Noviembre & Diciembre & Enero & Febrero \\
\hline Bejaria sp. & 12 & 123 & 23 & 14 \\
Clusia multiflora & 6 & 9 & 0 & 5 \\
Centropogon sp. & 3 & 2 & 12 & 10 \\
Fuchsia boliviana & 25 & 35 & 52 & 104 \\
Abutilon spp. & 205 & $\mathbf{2 9 2}$ & $\mathbf{8 8}$ & $\mathbf{1 3 3}$ \\
\hline Total Visits & $\mathbf{2 5 1}$ & & \\
\hline
\end{tabular}

pollen was noted on the bird's bill or plumage when it was captured). Typically, the bird visited several flowers during a feeding bout, then perched nearby before returning to forage. It ranged widely in the general area while foraging, and was never seen to defend particular flowers against other visitors. It also made short sallies from a perch to engage in intricate flycatching maneuvers in swarms of small flies, especially at midday on sunny days when these insects were most active; by contrast, flower visits were mostly concentrated in the morning or late afternoon hours.

The Rogitama hummingbird was not seen to defend a feeding territory, probably because dense aggregations of flowers were also visited and sometimes defended by larger, more dominant hummingbirds (Colibri coruscans, Campylopterus falcatus and Coeligena prunellei). When its visits coincided with theirs, the Rogitama hummingbird was quickly expelled and sometimes chased by these species. No interactions were observed between the Rogitama hummingbird and smaller hummingbirds (A. melanogenys, C. poortmannii and C. mulsanti), even when visiting adjacent flowers. Passerine nectarivores (Diglossa humeralis and albilatera, Coereba flaveola) were common to abundant at Rogitama and few interactions with the Rogitama hummingbird were seen, but in all cases the latter was attacked and quickly driven away from the flowers it was visiting.

For comparing the song of the Rogitama hummingbird with those of its putative parental species, we consider "song" to be a prolonged, more or less elaborate vocalization delivered from a perch. One might expect that the song of the Rogitama bird would be intermediate between those of its parent species, or to include elements of one or both of them. However, this is decidedly not the case (Figure 2). The song of A. kingi consists of a low-pitched introductory syllable, then a brief second syllable (ca. $6 \mathrm{kHz}$ ) followed by seven repetitions of a third syllable at $6-7 \mathrm{kHz}$, the last two louder and higher-pitched (ca. $8 \mathrm{kHz}$ ), a higher-pitched repetition of the second syllable $(7-8 \mathrm{kHz})$ followed by three slower-paced repetitions of a down-slurred fourth syllable with a broader frequency range (ca. 10-6 kHz); the total duration of the song is ca.1.3s. The song of $M$. tyrianthina is a more elaborate medley of 6 different syllable types, delivered over $c a$. 1.7s. These syllables mostly cover a broad frequency range with the dominant frequencies around 6-8
$\mathrm{kHz}$. By contrast, the song of the Rogitama hummingbird is much simpler in structure, consisting of a prolonged (ca. $3 \mathrm{~s}$ ), high-pitched trill or twitter involving rapid repetition (ca 12/s) of a single syllable type with a distinct first harmonic, that increases in intensity while decreasing in pitch from ca. 11 to $8 \mathrm{kHz}$, slowing from 12/s to 10/s over the final syllables. The single syllable type of this song does not correspond to any of the syllables of the songs of either parent species and the overall duration of the song is much longer than those of either parent.

\section{Discussion}

One of the prime requisites of hybridization among hummingbirds cited by Banks \& Johnson (1961) was rarity of one or both parental species in the area, such that both might have difficulty in finding a conspecific mate. This appears to be the case at Rogitama, where both species (especially A. kingi) are very uncommon. Although A. kingi has been recorded to $3000 \mathrm{~m}$, it is considered rare above $2500 \mathrm{~m}$ in the Colombian Andes (Hilty \& Brown 1986). M. tyrianthina has been recorded as low as $1700 \mathrm{~m}$ in Colombia, but it is usually found above 2400 m (Hilty \& Brown 1986) and most abundantly above ca. 2600m. The two species differ in behavior as well: A. kingi occurs more in forest canopy (especially males; females more often in the understory) and rarely is territorial, while $M$. tyrianthina occurs mostly at low to midlevels in forest but also in forest edges and matorral; males also are notably aggressive and frequently territorial at flowers (Hilty \& Brown 1986, FGS pers. obs.). Therefore, the mating of a male $M$. tyrianthina with a female $A$. kingi would seem much more likely than the reverse on behavioral grounds.

Further support for this parentage of the Rogitama hummingbird is the study by Graves (1998) of a hybrid between A. kingi and $M$. tyrianthina from Venezuela. Its plumage was very similar to that of the Rogitama hummingbird, even including the "hybrid bluing" of the body plumage, in spite of its parents belonging to different subspecies from those of Colombia. Graves (op. cit.) also mentioned the description of a hybrid with very similar plumage by Meyer de Schauensee (1947), for which previous authors had suggested three different hypotheses of its parentage, including A. kingi x R. microrhynchum! 

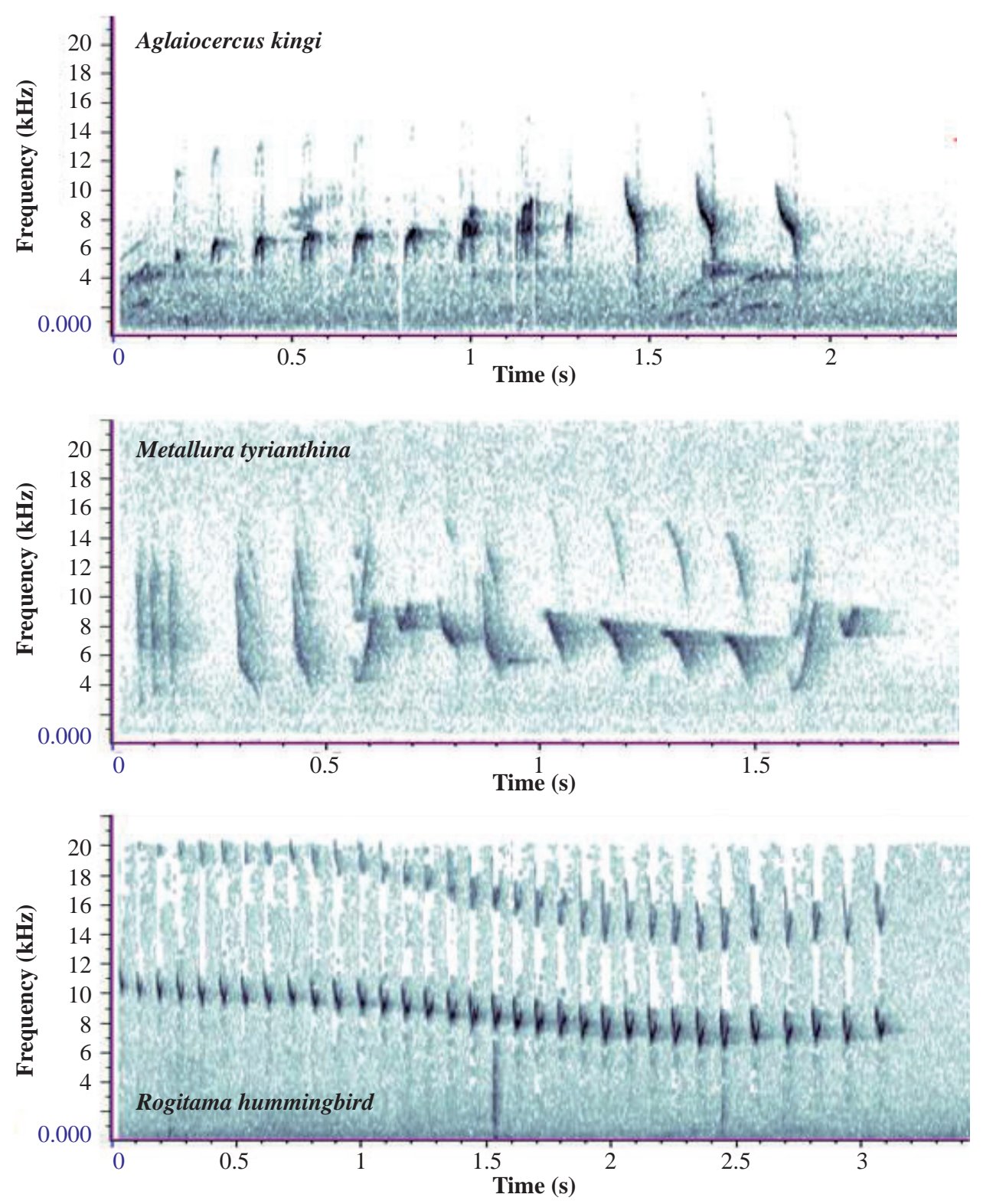

Figure 2. Songs of males of Aglaiocercus kingi, Metallura tyrianthina and the Rogitama hummingbird. Note the simpler structure and greater length of the song of the Rogitama hummingbird, and that the single repeated syllable of this song does not correspond to any of the elements of the songs of the parental species.

Although most instances of hybridization in hummingbirds have been determined from study skins, some recent cases have been discovered and studied "in vivo", permitting comparisons of songs and displays of the hybrids with those of the parental species (e.g., Wells et al. 1978, Clark et al. 2012, 2013, Graves 2015). We observed nothing that could be construed as a courtship display by the Rogitama hummingbird; to judge from the fresh condition of its plumage with no signs of molt when captured, it had completed molt relatively recently and probably was not in breeding condition. Most forest hummingbirds of the upper Eastern Andes breed from about March through July or August (Hilty \& Brown 1986, FGS pers. obs), so the departure of the Rogitama hummingbird in April might have been motivated by its returning to the area where it was hatched (presumably at no great distance from Rogitama?). In any case, the fact that its song had virtually nothing in common with those of its parental species is of particular interest in that it apparently represents a "transgressive" character state (not present in either parental species), a condition rarely observed in hybrids (Graves 2006; see Wells et al. 1978 for an example in displays, Clark et al. 2013 for an example in plumage morphology). Wells et al. (op. cit.) suggested that such characters might represent states latent in the genome of one parent, inherited from its common ancestor with another species and only expressed 
in the hybrid. However, the "hybrid bluing" of the Rogitama hummingbird and other crosses mentioned by Graves (1998) could also be interpreted as a transgressive character, for which the explanation of Wells et al. (op. cit.) seems unlikely.

Banks \& Johnson (1961) also noted that hybridization in North American hummingbirds was between species of different genera and suggested that this reflected the fact that congeneric species occupied breeding ranges with little or no overlap, and that congeners might have developed stronger isolating mechanisms more recently in conjunction with geographical separation. They also suggested that alternatively, the genera of at least North American hummingbirds were oversplit. The recent phylogeny of the hummingbirds by McGuire et al. (2014) suggested only one lumping (of Stellula into Selasphorus) which did produce two instances of hybridization of congeners, but a number of instances of hybridization between congeners are known among South American hummingbirds (and several cases among undoubted congeneric species in North America have also come to light (e.g., Wells et al. 1978).

However, it does appear that most instances of hybridization in hummingbirds do involve genera and species in the same major clade, as is the case of the Rogitama Hummingbird (both parents are members of the "coquette" clade 3, cf. McGuire et al. (2014) and most other instances involve species in this clade, clade 7 (the "bees", which include the North American species studied by Banks \& Johnson), the "brilliants" of clade 4, the "emeralds" of clade 8 and possibly the hermits (clade 1). A comprehensive summary of avian hybridization (McCarthy 2009) disclosed that of 26 reported cases of intergeneric hybrids in hummingbirds, 21 involved genera in the same major clade. This may reflect in part the fact that different major clades may show different elevational distributions. Most members of the "coquette" clade occur at middle to high elevations in the Andes, whereas those of the "brilliants" are especially characteristic of middle elevations in this range and the "emeralds" and "hermits" are almost exclusively birds of the tropical lowlands (Stiles 2008). Another factor perhaps contributing to hybridization may be migration: among the "bees" of North America, the species breeding furthest north pass through the breeding areas of more southern species which may already be breeding, providing opportunities for interspecific matings. The promiscuous breeding system of hummingbirds, involving only brief contacts between male and female during courtship and copulation, may ultimately be responsible for the large number of reported hybrids in this family. Although numerous hybrids have been reported in groups frequently kept and bred in captivity (e. g., gallinaceous and psittacine birds, pigeons and doves, ornamental finches in at least two families), all hybrid hummingbirds were collected or observed in the wild.

\section{Acknowledgments}

First and foremost, we thank Roberto Chavarro and his family for their hospitality, including permitting us to observe and capture the Rogitama hummingbird. Their efforts in conservation and habitat restoration made this study possible. Gary Graves generously supplied photos of the type specimen of Heliangelus zusii and several references and made many helpful comments on the manuscript, as also did Alejandro Rico. We thank Jurgen Beckers for permission to use two of his photographs of the Rogitama hummingbird.

\section{Conflict of interests}

The authors declare no conflicts of interest of any kind.

\section{Bibliography}

Banks, R. C. \& N. K. Johnson. 1961. A review of North American hybrid hummingbirds. Condor 63: 3-28.

Chavarro, R. 2009. Rogitama biodiversidad. BV News 1: 11-13.

Clark, C. J., T. Feo \& K. B. Bryan. 2012. Courtship displays and sonation of a Broad-tailed x Black-chinned Hummingbird. Condor 114: 329-340.

Clark, C. J., T. Feo \& W. van Dongen. 2013. Sounds and courtship displays of the Peruvian Sheartail, Chilean Woodstar, Oasis Hummingbird and a hybrid Peruvian Sheartail x Chilean Woodstar. Condor 115: 558-575.

Graves, G. R. 1993. Relic of a lost world: a new species of sunangel (Trochilidae: Heliangelus) from "Bogotá”. Auk 110: $1-8$.

Graves, G. R. 1997. Diagnoses of hybrid hummingbirds (Aves: Trochilidae) 3. Parentage of Lesbia ortoni Lawrence. Proceedings of the Biological Society of Washington 110: 314-319.

Graves, G. R. 1998. Diagnoses of hybrid hummingbirds (Aves: Trochilidae) 6. An intergeneric hybrid, Aglaiocercus kingi $x$ Metallura tyrianthina, from Venezuela. Proceedings of the Biological Society of Washington 111: 511-520.

Graves, G. R. 1999. Diagnoses of hybrid hummingbirds (Aves: Trochilidae) 8. A new hypothesis for the hybrid origin of Zodalia glyceria (Gould, 1858). Proceedings of the Biological Society of Washington 112: 491-502.

Graves, G. R. 2007. Diagnoses of hybrid hummingbirds (Aves: Trochilidae) 16. Characters of a striking intergeneric hybrid (Lampornis clemenciae x Calypte anna) from Ramsey Canyon, Huachuca Mts., southeastern Arizona. Proceedings of the Biological Society of Washington 113: 6-25.

Graves, G. R. 2015. A primer of the hybrid zone of Jamaican streamertail hummingbirds (Trochilidae, Trochilus). Proceedings of the Biological Society of Washington 128: 111-124.

Hilty, S. L. \& W. L. Brown. 1986. A guide to the birds of Colombia. Princeton University Press, Princeton, NJ. 
McCarthy, E. M. 2009. A handbook of avian hybrids. Oxford University Press, Oxford, UK.

McGuire, J. A., C. C. Witt, J. V. Remsen, Jr., A. Corl, D. L. Rabosky, D.L. Altshuler \& R. Dudley. 2014. Molecular phylogenetics and the diversification of hummingbirds. Current Biology 24: 1-7.

Meyer de Schauensee, R. 1947. New or little-known Colombian birds. Proceedings of the Academy of Natural Sciences of Philadelphia 99: 107-126.

Stiles, F. G. 2004. Phylogenetic constraints upon morphological and ecological adaptation in hummingbirds (Trochilidae): why are there no hermits in the páramo? Ornitologia Neotropical 15 (suppl.): 191-198.

Stiles, F. G. 2008. Ecomorphology and phylogeny of hummingbirds: divergence and convergence in adaptation to high elevations. Ornitologia Neotropical 19 (suppl.): 511-519.

Stiles, F. G., D. A. Altshuler \& R. Dudley. 2005. Wing morphology and flight behavior of some North American hummingbird species. Auk 122: 872-886.

Wells, S., R. A. Bradley \& L. F. Baptista. 1978. Hybridization in Calypte hummingbirds. Auk 95: 537-549. 